\title{
Understanding the Moderating Role of Islamic Work Ethics between Job Stress and Work Outcomes
}

\author{
Muhammad Umar Bin Ajmal, Sana Irfan \\ Foundation University Rawalpindi Campus \\ Foundation University Rawalpindi Campus
}

\begin{abstract}
This study reveals the moderating role played by Islamic Work Ethics between job Stress and Work Outcomes (Turnover intention, Job Satisfaction). Data were gathered from 120 employees of Private and government, educational institute teachers and bankers, mediating mode of data gathering was Questionnaires. The results show significant negative relation of job stress with job satisfaction and significant positive relation with turnover intention. Islamic Work Ethics turns significant relation of job stress with job satisfaction and strengthen relation with turnover intention. The study provides interesting guide lines to managers in formulation of human resource policies. Limitations and future recommendations are discussed.
\end{abstract}

Keywords: Islamic Work Ethics, Job Stress, Turnover intention, Job Satisfaction.

Research Type: Research paper

\section{Introduction:}

In behavioral sciences understanding the theory of stress is very much vital, when stimulus or response or both are joined defines the term 'stress' in broad perspective (George, 2007). while, growing frequency of a popular phrase Job stress is evident, many researchers are doing research on job stress, we can say that job stress in fashion for researchers, particularly in social sciences, organizations are accounting the truth that due to job stress human potential is getting weak (Muhammad et al. 2011). Many people believe that job stress is due to work overload, working for huge hours, job insecurity and rate of change in life (American Psychological Association, 1997). In contrast, Turnover is a result of work stress, has created interest in many researchers (Richer et al. 2002). Turnover is defined as the "individual movement across the membership boundary of an organization" (Price, 2001) . It is evident in behavioral sciences work stress results due to poor employee performance, absenteeism and high turnover (Porter \& Steers, 1973). Meanwhile, apart from turnover, we cannot deny the worth of another out of work stress, job satisfaction. Employee's perception or job appraisal can build satisfying or arousing condition defines the term job satisfaction in bold terms (Locke, 1976) . In general, job stress has been viewed as an antecedent of job satisfaction (Stanton et al. 2002). On consistent basis, literature shows that job stress has an opposing relation with job satisfaction depending upon range of population (Beehr et al. 1976), (Cotton et al. 2002) .Therefore, we can say that job satisfaction and turnover intention come under the umbrella of job stress. However, ideological foundation of different personal attributes can be developed by learning Islam (Ali, 1992). Without a doubt, (Ali \& J.A, 2005) noted that when Islamic Ethics were applied. The Islamic work ethic stands not for the life denial but for the life fulfillment and regards business motives as one of the priorities of life (Ahmad, 1976). Results show, high job satisfaction and high organizational commitment is shown by those employees who have strong belief in Islam and follow Islamic ethics and at the same time they show low turnover intention (Wahibur, 2010) .

It is important to know some reasons to understand business ethics in Islamic perspective. First of all, the second largest religion in the world which beliefs in the oneness of God is Islam. There are about $22.5 \%$ Muslims in the world's population and this Muslim population is growing above 1.5 times faster as compared to overall population (Johnson and Grim 2013). Secondly, there is a huge customer representation and have big investment in Western Countries by Muslims (Saeed et al. 2001). Third, the need for a greater appreciation of workforce diversity in the face of globalization and heightened competition across the globe demands researchers and practitioners to understand the critical role of various religious and social factors that influence businesses (Uddin \& J. S, 2003). A religion always motivate people spiritually to accomplish a certain goal (Ali et al. 1995).Islamic Work Ethics defines work as a promoter of social relationships and one's growth (Ali, 2008) .Islamic Work Ethics always supports a person who has a hunger of legal income source and is dedicated to work. Islamic Work Ethics also appreciates economic activity involvement of its believer (Yousef, 2000a) .So we can say that people with high Islamic Work Ethics belief are more satisfied and can show better performance as compared to low ISLAMIC WORK ETHICS believers. On the whole, there is high job satisfaction, high organizational commitment can be found in such employee who belief strong in Islam and follow ethics said in Islam (Wahibur, 2010). 
To have more confident generaliabilty researchers are doing research to enhance theories on organization to Eastern settings (Tsui \& AY, 2007). The gap between non western and western settings can be filled by this study.

\title{
Theory and hypothesis:
}

\section{Job Stress and Job Satisfaction/ Turnover Intention}

Many studies reveal that job satisfaction of an employee and performance is influenced by stress, this is because better outcomes of jobs are on demand for organizations. Indeed this modern time is termed as "the age of anxiety and stress" (Mahdad, 2006). The degree of anxiety's tension felt by an employee reasoned by their job is job stress (Gill \& Shacha, 2006). Job stress can also be defined as "the harmful physical and emotional responses that occur when the requirements of the job do not match the capabilities, stress and the resources, or needs of the worker (Rode, 2004). Both the organization and its employees can be highly affected in result of work stress. The organization could not get its forecasted goals of a particular job and job dissatisfaction element could also be experienced and at the same time this organization would have to bear cost for this. Municipality personnel are often affected by this one factor (Solaymannezhad, 2004).

Job satisfaction is "a pleasurable or positive emotional state resulting from the appraisal of one's job or job experiences" (Locke E. , 1983). Working manners and overall performance can be forecasted by engagement. Profit to the organization comes from engaged employees, customer focused, and safe employees and they resist the appeal to leave (Gallup Organization, 2008).

Job satisfaction can be determined by four factors. First, psychological demanding activities for every employee. Second, fair and unbiased reward system for employees aligned with their expectations. Third, working conditions must have to be supportive. Fourth, every employee must support and try creating an atmosphere of relationship at work "having friendly and supportive co-workers leads to practitioners increased job satisfaction" (Rizzo et al. 1970).

Under job satisfaction model, Herzberg's Theory of Motivation, declared bi-directional pattern factors which affect attitude towards work, can be named as job satisfaction's base theory (Herzberg, 1959). These factors can be employees relationship at work, working conditions and pay package are hygiene factors more willingly than encouraging factor in relation to job satisfaction. Encouraging factors such as accomplishment, acknowledgment, display of responsibility and encroachment are counted as muscular components of job satisfaction (Syptak, 1999).

Motivational theory and definition of job satisfaction are somehow same, whereas, appraisal raise for every employee within the organizations environment can be provided under enjoyable and positive state. Both motivational theory and job satisfaction enlightens hygiene and motivation factors (Herzberg, 1959).

Few studies attempted to build linkage between job satisfaction and stress. Human resource management researchers are focusing on job stress and job satisfaction. Researchers found a considerable relationship between job stress and job satisfaction (Stamps, 1986).

Turnover intention is a mental decision intervening between an individual's attitude regarding a job and the stay or leaves decision (Sager, 1998). Three elements are focused in turnover intention: i) the thinking of quitting, ii) the intention to search for another job elsewhere and iii) the intention to quit (Miller et al., 1979; Mobley et al., 1979). Individual's job satisfaction is influenced by job stress which results in down fall of performance and turnover intention (Applebaum et al, 2010).

\author{
Hypothesis \\ 1a. Job stress negatively effects job satisfaction. \\ 1b. Job stress positively effects turn over intention.
}

\section{Islamic Work Ethics (IWE)/Job stress/Turnover}

Difference between right and wrong can be established on the basis of ethics (Khurram Khan, 2013). For educational, trade, governments and common public knowing ethics and dimensions of trading is an important subject (Ahmed et al. 2003); (Crane et al. 2007); (Sen, 1993) .Ethics are emerged from Weber's theory of protestant work ethics, in west it is highly considered for business ethics research (Yousef, 2000a). Islamic Work Ethics is newly introduced by (Ali A. , 1988)focusing Islamic ethical activities in businesses. Holy Quran and Prophet Muhammad (S.A.W.W) taught Islamic Work Ethics (Ali and Al-Owaihan 2008); (Rice, 1999); (Yousef, 2000a). For every person who accepted Islam can learn principles and can get guidelines to conduct Islamic way of living and these teachings are accepted for all times (Beekun \& Badawi, 2005). Peace is the actual meaning of "Islam", a man can get peace if he is obedient to Allah's or God's will in every matters of life. (Abuznaid, 2006); (Syed, 2010) .In Islam, for illustration, "it is the ethic that dominates economics and not the other way around" (Rice, 1999) and whatever one do, Islamic ethics and values are judging it. So, 
Muslims have to have follow codes written in Shariah (Islamic Law and Jurisprudence). Accordingly, it is the duty of every Muslim to accept Allah's will (Syed, 2010).

Islam provided simple and comprehensive setups, based on ethics, which regulates every aspect of life accounting social and economic activities (Naqvi, 1981); (Rice, 1999). Not only individual lives, collective lives are also covered in it (Beekun, 1997).All aspects of lives of Muslims must show and reflect religious beliefs (Syed and Ali, 2010). Moreover, Islamic law explains Islamic Work Ethics which cannot be changed nor denied and are same of every Muslim, so, Islamic Law is not for some specific field persons or society. In Islamic societies, Cultural norms and values have roots in Islamic principle and they grow according to take shape according practices made by Muslims, as directed by the Shariah instead of traditions, as a separate standard, driving approaches and behaviors of the believers (Ali and Al-Owaihan 2008)). For that reason, Islamic Work Ethics is part of Muslims faith setup. Many times in Quran, explained that creative job is an element of religious obligation and at the same time there relationship is also mentioned in it (Abeng, 1997). Such as, Quran says "and he who does righteous deeds and he is a believer, he will neither have fear of injustice nor deprivation" (20:112) and "for those who were believers and they did righteous deeds, are the Gardens as accommodation for their deeds" (32:19). Furthermore, Prophet Muhammad (S.A.W.W.) said that sins are waived off by hard work and the food ate by a person by his work is the best food (Ali , 1992); (Ali and Gibbs., 1998). In Islamic Work Ethics, success, fulfilling oneself and to get peace of mind is achieved by work (Nasr, 1985). In addition, employees turnover intent can be predicated by Islamic Work Ethics Research imply, Islamic Work Ethics oriented employees have less rate of turnover (Ahmad, 2011). Therefore, it can be believed that such employees are with less turnover intent, more satisfied, show high job involvement who are high in Islamic Work Ethics.

Hypothesis

2a. Islamic Work Ethics is positively related to Job satisfaction.

2b. Islamic Work Ethics is negatively related to Turnover intention

While Islamic Work Ethics stresses upon trustworthiness, hard work and self-respect (Ali, 1992),as a result, moderating affiliation between job stress and job satisfaction, and affliation between job stress and turn over intention can be predicted, nothing like western context. In the same way, individual's integral belief system can be driven by religion, suggested by research on religiosity and individual's natural and learnt work values are drastically influenced (Parboteeah et al. 2009). As Islamic Work Ethics is an important part of Muslim beliefs and value system, those employees who are high in Islamic Work Ethics are high in job satisfaction and job involvement and are low in turn over intention. Hence we can hypothesize that;

\section{Hypothesis 3}

3a. Islamic Work Ethics moderates the negative relationship between job stress and job satisfaction in such a way that the relationship will be weak when Islamic Work Ethics is high.

3b. Islamic Work Ethics moderates the positive relationship between job stress and turnover intention in such a way that relationship will be weak when Islamic Work Ethics is high.

Theoretical Frame Work

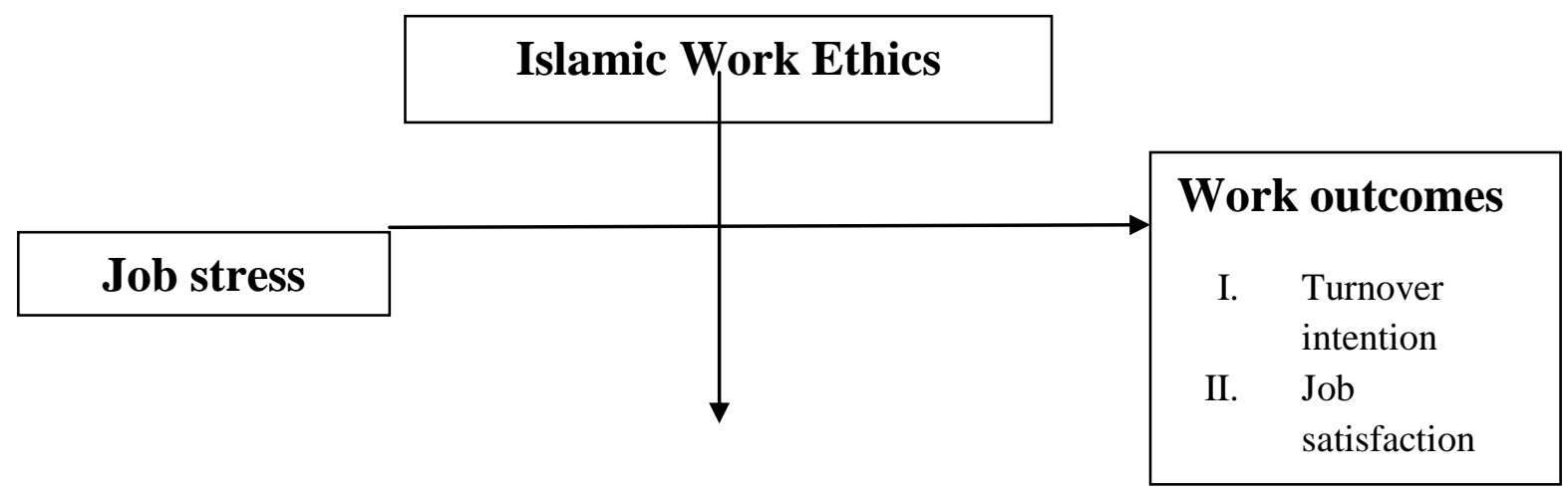




\section{Methodology:}

The research was conduct in different educational institutes, banks, and government and private organizations in Rawalpindi. A five-point scale questionnaire was adopted to carry out results. A total of 120 questionnaires were collected. For Islamic Work Ethics, Job Satisfaction and Turnover Intention, scale range was 1 (strongly disagree) to 5 (strongly agree) and for job stress, scale range was 1 (very often) to 5 (never).

\section{Reliability}

\begin{tabular}{|l|l|}
\hline Variable & $\alpha$ \\
\hline Job stress & .854 \\
\hline IWE & .763 \\
\hline Job satisfaction & .799 \\
\hline Turnover intention & .786 \\
\hline
\end{tabular}

Crone back $\alpha$ of Job stress, Islamic Work Ethics, Job Satisfaction and Turnover Intention is indicated in above table.

\section{Correlation}

\begin{tabular}{|l|l|l|l|}
\hline & Stress & $\begin{array}{l}\text { Islamic } \\
\text { Work Ehics }\end{array}$ & Job Satisfaction \\
\hline & & & \\
Islamic Work Ehics & $-.241^{* *}$ & & \\
& .008 & & \\
& 120 & $.267^{* *}$ & \\
Job Satisfaction & -.127 & .003 & \\
& .168 & 120 & \\
Turnover & 120 & -.113 & $-.365^{* *}$ \\
& $.335^{* *}$ & .220 & .000 \\
& .000 & 120 & 120 \\
\hline
\end{tabular}

The above results show

- $\quad$ Islamic Work Ethics and Stress has stronger significance level.

- Job Satisfaction and Islamic Work Ethics has stronger significance level.

- Turnover Intention and Job Satisfaction also has stronger negative significance level.

Regression

Job Stress

Job stress x IWE

\section{Job satisfaction}

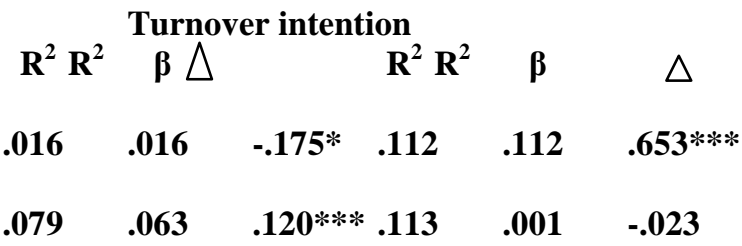

The above results show:

- Job stress has a negative relation with job satisfaction; the strength of the relation is strong. So, whenever job stress extent is increased job satisfaction will be decreased in same fashion. May be due to number of reasons like work overload, relationship with colleagues and other employees, organization's rules and regulations, less chance of promotion, job security an individual feel stress which result in job dissatisfaction.

- Job stress in presence of Islamic Work Ethics is positively related to job satisfaction, Strength of the relation is strongest. Islam highly focuses on patience, tolerance, brotherhood that is why Islamic Work Ethics positively moderate the relation between job stress and job satisfaction.

- Job stress is positively related to turnover intention and the relationship is highly significant. This is because whenever an individual is affected by job stress his satisfaction level will be low and he will seek better opportunities which results in high turnover intention.

- Job stress and Islamic Work Ethics have an insignificant negative effect on turnover intention because Islam urges individual to hold his patience to maximum level. May be respondents did not understand the asked questions or there may be a possibility that respondents were of different mind sets. 


\section{Conclusion, Limitation and Future Recommendation:}

This study carry outs the moderation role of Islamic Work Ethics between Job stress and Job Outcomes. It is clear from this study that between job stress and job satisfaction there is negative relation and when ever Islamic Work Ethics is introduced as a moderator, it strengthens their relationship even more. This study reveals that job stress has positive impact on turnover intention and when their relationship is tested with Islamic Work Ethics as a moderator, it shows insignificant negative relationship with each other.

Due to the shortage of time and scarce resources, this study was done on very short scale. There were few respondents who could not get time to respond on time.

For have more study, bigger sample and geographical size and maximum time should be used. Researchers may use performance at job, organizational commitment and other elements for future study.

\section{Reference}

[1]. Muhammad Jehangir, Dr. Nasir Kareem, Dr. Ayaz Khan, Muhammad Tahir Jan, Dr. ShaheedSoherwardi. Effects of job stress on job performance \& job satisfaction. Interdisciplinary journal of contemporary research in business. Vol 3, No 7 (November 2011)

[2]. Richer, S.F., C. Blanchard and R.J. Vallerandi, 2002.A Motivational Model of Work Turnover. Journal of 30Applied Social Psychology, 32(10): 2089-2113.

[3]. Price, J. (2001). Reflections on the Determinants of Voluntary Turnover. International Journalof Manpower 22, 600-624.

[4]. Porter, L.W; \& Steers, R.W. Organizational, Work, and Personal Factors in Employee Turnover and Absenteeism. Psychological Bulletin, 1973, 80, 151-176.

[5]. Locke, E.A. The Nature and Causes of Job Satisfaction. In M.D. Dunnette (ed.), Handbook of Industrial and Organizational Psychology. Chicago: Rand-McNally, 1976.

[6]. Beehr, T.A., Walsh, J.T., \& Taber, T.D. (1976). Perceived situational moderators of therelationship betweensubjective role ambiguity and role strain, Journal of Applied Psychology, 61, pp.35-40.

[7]. Sarah J. Cotton, Maureen F. Dollard, and Jan de Jonge, Stress and Student Job Design:Satisfaction, Well-Being, and Performancein University Students, International Journal of Stress Management, Vol. 9, No. 3, July 2002

[8]. Jagdish K. Dua, (1994) "Job Stressors and Their Effects on Physical Health, Emotional Health and Job Satisfaction in a University", Journal of Educational Administration, Vol. 32 Iss: 1, pp.59 - 78

[9]. Hawe, E., Tuck, B., Manthei,R., Adair, V., \& Moore, D. (2000). Job satisfaction and stress inNew Zealand primary teachers. New Zealand Journal of Educational Studies, 35, 193-205.

[10]. Heslop, P., Smith, G. D., Metcalfe, C., Macleod, J., \& Hart, C. (2002). Change in jobsatisfaction,and its association with self-reported stress, cardiovascular risk factors andmortality. SocialScience and Medicine, 54, 1589-1599.

[11]. Lu, L., Shiau, C., \& Cooper, C. L. (1997). Occupational stress in clinical nurses. CounselingPsychology Quarterly, 10(1), 39-50.

[12]. Richardsen, A. M., \& Burke, R. J. (1991). Occupational stress and job satisfaction amongphysicians: Sex differences. Social Science and Medicine, 33, 1179-1187.

[13]. Ulleberg, P., \&Rundmo, T. (1997). Job stress, social support, job satisfaction and absenteeismamong offshore oil personnel. Work and Stress, $11,215-228$

[14]. Ali, J.A. (1992). Islamic work ethic in Arabia. Journal of Psychology, 126(5): 507-517.

[15]. Ali, J.A. (2005). Islamic Perspectives on Management and Organization. Edward Elgar Publishing, UK.

[16]. WahiburRokhman. (2010), The Effect of Islamic Work Ethics on Work Outcomes, EJBO Electronic Journal of Business Ethics and Organization Studies

[17]. Saeed, M., Ahmed, Z. U., \&Mukhtar, S. (2001). Internationalmarketing ethics from an Islamic perspective: A valuemaximizationapproach. Journal of Business Ethics, 32, 127-142.

[18]. Uddin, S. J. (2003). Understanding the framework of business inIslam in an era of globalization: A review. Business Ethics: AEuropean Review, 12(1), 23-32.

[19]. Eastman, W., \& Santoro, M. (2009). The importance of valuediversity in corporate life. Business Ethics Quarterly, 13(4),433-452.

[20]. Ali, J. A., \& Al-Owaihan, A. (2008). Islamic work ethic: A criticalreview. Cross Cultural Management: An International Journal,15(1), $5-19$.

[21]. Yousef, D. A. (2000a). Organizational commitment as a mediator ofthe relationship between Islamic work ethic and attitudes towardorganizational change. Human Relations, 5, 513-537.

[22]. Tsui AS, Nifadkar SS, Ou AY (2007). Cross-national, cross-cultural organizational behavior research: Advance, gaps and recommendations. J. Manag. 33(3):426-478.

[23]. Mahdad, A., 2006. Industrial and organizational psychology, Jungle Institute, pp: 4

[24]. Gill, A., A. Flaschner and M. Shachar, 2006. Mitigating stress and burnout by implementing transformational-leadership. International Journal of Contemporary Hospitality Management,18(6): 469-481.

[25]. Rode, J.C., 2004. Job Satisfaction and Life Satisfaction Revisited: A Longitudinal Test of anIntegrated Model, HumanRelations, 57(9): $1205-1231$

[26]. Solaymannezhad, H., 2004. The relationship betweenjob stress and job satisfaction in government organization in Ilam, Master thesis, Ilam Islamic Azad University, Iran.

[27]. Locke, E., 1983. The nature and causes of jobsatisfaction. In M.D. Dunnette ((Ed.) Handbook of Industrial and Organizational Psychology,bepp: 1297-1349. New York, NY: John Wiley andsons,Inc.

[28]. Gallup Organization, 2008. Employee engagement. Retrieved February 19

[29]. Rizzo, J.R., R.J. House and S.I. Lirtzman, 1970.Role conflict and ambiguity in complexorganizations, Administrative Science Quarterly, 15: 150-63.

[30]. Herzberg, F., B. Mausner and B. Snyderman, 1959. The motivation to work. New York, NY: John Wiley. Hair, J.F. R.L. Tatham, R.E. Anderson and W. Black, 1998. Multivariate DataAnalysis (5th Ed.). Prentice Hall.

[31]. Syptak, J., D. Marsland and D. Ulmer, 1999. Job satisfaction: Putting theory into practice.Family Practice Management. 6(9): 26-30. Retrieved January 16

[32]. Stamps, P.L. and E.B. Piedmonte, 1986. Nurses and work satisfaction: An index for measurement. Ann Arbor,MI: Health Administration Press Perspectives

[33]. Sager, J.K., Griffeth, R.W. \&Hom, P.W. (1998). A comparison ofstructural models representing turnover cognitions. Journalof Vocational Behaviour, 53(2), 254-273. 
[34]. Khurram Khan, Muhammad Abbas, AsmaGul and Usman Raja, 2013. Organizational Justice and Job Outcomes: Moderating Role of Islamic Work Ethic, The ethics of business in a global economy, Springer.

[35]. Ahmed, M. M., Chung, K. Y., \&Eichenseher, J. W. (2003). Businessstudents' perception of ethics and moral judgment: A crossculturalstudy. Journal of Business Ethics, 43, 89-102.

[36]. Crane, A., \&Matten, d. (2007). Business ethics: Managing corporatecitizenship and sustainability in the age of globalization. Oxford:Oxford University Press.

[37]. Sen, A. (1993). Does business ethics make economic sense; In P.M. Minus (Ed.), The ethics of business in a global economy (pp.5366). Dordrecht: Springer.

[38]. Ali, A. (1988). Scaling an Islamic work ethic. The Journal of SocialPsychology, 128(5), 575-583.

[39]. Ali, J. A., \& Al-Owaihan, A. (2008). Islamic work ethic: A criticalreview. Cross Cultural Management: An International Journal,15(1), 5-19.

[40]. Rice, G. (1999). Islamic ethics and the implications for business.Journal of Business Ethics, 18, 345-358

[41]. Beekun, R. I., \&Badawi, J. A. (2005). Balancing ethical responsibilityamong multiple organizational stakeholders: The Islamicperspective. Journal of Business Ethics, 60(2), 131-145.

[42]. Abuznaid, S. (2006). Islam and management: What can be learned?Thunderbird International Business Review, 48(1), 125-139.

[43]. Syed, J., \& Ali, A. J. (2010). Principles of employment relations inIslam: A normative view. Employee Relations, 32(5), 454-469.

[44]. Naqvi, S. N. H. (1981). Ethics and economics: An Islamic synthesis(Vol. 2). London: Islamic Foundation.

[45]. Beekun, R. I. (1997). Islamic business ethics. IslamKotob.

[46]. Ali, A. J., \& Gibbs, M. (1998). Foundation of business ethics incontemporary religious thought: The Ten Commandment perspective.International Journal of Social Economics, 25(10),1552-1564.

[47]. Ahmad, M. S. (2011). Work ethics: An Islamic prospective.International Journal of Human Sciences, 8(1), 850-859

[48]. Parboteeah, K. P., Paik, Y., \& Cullen, J. B. (2009). Religious groupsand work values: A focus on Buddhism, Christianity, Hinduismand Islam. International Journal of Cross Cultural Management,9(1), 51-67. 